\title{
Knowledge Acquisition, Innovativeness and Product Innovation in the Textile Sector
}

Versão do autor aceita publicada online: 08 out. 2021

Publicado online: 25 out. 2021

Como citar esse artigo - American Psychological Association (APA): Ganzer, P. P., Matte, J., Toni, D., Milan, G. S., \& Olea, P. M. (2021). Knowledge Acquisition, Innovativeness and Product Innovation in the Textile Sector. Exacta. DOI: https://doi.org/10.5585/exactaep.2021.20044.

\section{Paula Patricia Ganzer}

ganzer.paula@gmail.com

http://orcid.org/0000-0003-4006-6517

Instituto Federal do Rio Grande do Sul (IFRS)

Pós-Doutora em Administração no Programa de Pós-Graduação em Administração na Universidade de Caxias do Sul, UCS, Brasil. Doutorado em Administração pela Pontifícia Universidade Católica do Rio Grande do Sul, PUCRS, Brasil e pela Universidade de Caxias do Sul, UCS, Brasil (2017). Mestrado em Administração pela Universidade de Caxias do Sul, UCS, Brasil (2013). Graduação em Administração pelo Centro de Ensino Superior Cenecista de Farroupilha, CESF, Brasil (2010). Atuou como Bolsista de Iniciação Científica Voluntária junto ao Programa de Pós-Graduação em Administração, PPGA/UCS, no Projeto de Pesquisa Caracterização e Análise das Inovações no Setor da Saúde de Caxias do Sul (2010). Atuou como professora convidada no MBA em Inteligência de Mercado na FSG Centro Universitário da Serra Gaúcha (2017). PRODUÇÃO CIENTÍFICA: 70 artigos publicados em periódicos (ou revistas nacionais e internacionais). 109 artigos publicados em anais de eventos e 18 capítulos de livros publicados. PARTICIPAÇÃO EM BANCAS: 71 participações em Bancas, sendo: 64 em Graduação, 07 de Mestrado, 01 de Doutorado. OUTRAS INFORMAÇÕES: Associada ao CRA RS Conselho Regional de Administração do Estado do Rio Grande do Sul, à AANERGS - Associação dos Administradores da Região Nordeste do Rio Grande do Sul. ATUAÇÃO ACADÊMICA: Autora de artigos publicados em revistas nacionais e internacionais, capítulos de livros, artigos publicados em eventos científicos, no Brasil e no exterior nas áreas de Inovação e Empreendedorismo. Atua no Grupo de Pesquisa NIES - Núcleo de Inovação, Empreendedorismo e Sustentabilidade do Programa de PósGraduação em Administração da Universidade de Caxias do Sul. Avaliadora de artigos científicos em periódicos nacionais e eventos nacionais e internacionais. ATUAÇÃO PROFISSIONAL: Coordenadora dos Cursos de Graduação em Administração, Tecnologia em Processos Gerenciais e Tecnologia em Gestão de Recursos Humanos na Faculdade CNEC Farroupilha, Coordenadora Acadêmica da Empresa Júnior. Atua nas áreas de Empreendedorismo, Inovação, Gestão do Conhecimento e Inovatividade Organizacional em diversos setores econômicos com destaque no setor têxtil.

\section{Juliana Matte}

ju.cxs1@gmail.com

http://orcid.org/0000-0003-0945-2479

Universidade de Caxias do Sul (UCS)

Doutora em Administração no Programa de Pós-Graduação em Administração - PPGA da Universidade de Caxias dơ Sul - UCS com bolsa FAPERGS/CAPES. Mestre em Administração no Programa de PósGraduação em Administração - PPGA da Universidade de Caxias do Sul - UCS. MBA em Gestão Comercial pela Fundação Getúlio Vargas - FGV. Graduada em Administração com ênfase em Marketing pela Universidade Federal do Rio Grande do Sul - UFRGS. Integrante do Grupo de Pesquisa Núcleo de Inovação, Empreendedorismo e Sustentabilidade - NIES. Tem experiência na gestão estratégica no varejo. Tem experiência no setor bancário. Tem interesse na docência para os cursos de Administração e Marketing.

\section{Deonir de Toni}

deonirdt@terra.com.br

http://orcid.org/0000-0001-9637-8099 
e Consultor de Empresas nas áreas de estratégia e mercado há mais de 20 anos. PRINCIPAIS PRÊMIOS: Prêmios Mérito em Administração, no Setor de Ensino, em 2010, concedido pelo CRA RS, e Pesquisador Gaúcho, em 2013, concedido pela FAPERGS. CRA RS: 32.661. Scopus: h = 6. Web of Science: $\mathrm{h}=4$. Google Scholar: $\mathrm{h}=22$ e $\mathrm{i} 10=57$. SPELL: $\mathrm{h}=7$. ResearchGate: $\mathrm{h}=15$ e $\mathrm{RG}$ Score $=$ 31,14 .

\title{
Pelayo Munhoz Olea
}

pelayo.olea@gmail.com

http://orcid.org/0000-0003-2183-8112

Universidade Federal de Rio Grande

Resumo da Biografia Pós-Doutorado em Gestão Ambiental pela Universidad de Extremadura, UEX, Espanha, Bolsista do Programa de Intercâmbio de Formação de Investigadores entre a União Européia e a América Latina, Programa ALFA2 (América Latina Formación Académica) da Rede Jean Mermoz/ESPAÑA. Doutorado em Administração e Direção de Empresas pela Universitat Politècnica de Catalunya, ETSEIB/UPC, Espanha, Bolsista da Coordenação de Aperfeiçoamento de Pessoal de Nível Superior, CAPES/BRASIL. Mestrado em Engenharia de Fabricação de Papel pela Universitat Politècnica de Catalunya, ETSEIAT/UPC, Espanha, Bolsista do Instituto de Cooperación Iberoamericana, ICI/AECI/ESPAÑA. Graduação em Administração de Empresas pela Pontifícia Universidade Católica do Rio Grande do Sul, PUCRS e Graduação em Engenharia Mecânica pela Pontifícia Universidade Católica do Rio Grande do Sul, PUCRS.

\begin{abstract}
In this sense, this study aimed to test the relationship between knowledge management processes, innovativeness and product innovation in the Brazilian textile sector. The quantitative research was applied to 157 companies in the textile sector in Brazil registered with the Institute for Industrial Studies and Marketing (IEMI). Data analysis was performed using two statistical techniques: structural equation modeling and mediation and moderation tests. The results identified two significant constructs that positively impact product innovation. Innovativeness mediates the relationship between knowledge acquisition and product innovation, and the type of activity moderates the relationship of these constructs. Better business performance can be linked to a greater capacity for innovation. Knowledge acquisition, innovativeness, and product innovation are elements that, when related, potentiate the greater competitiveness of organizations. This study is relevant both to academia and to the strategic management of organizations.
\end{abstract}

Keywords: competitiveness, product management, knowledge acquisition, innovativeness, product innovation.

\section{Introduction}

The innovation capacity can explain why some organizations have superior performance to others in the same industry. Innovative companies manage to obtain a more significant 
competitive advantage and superior performance in their products, production processes, or managerial processes. As a consequence, firms can expand their ability to develop new products (Panizzon et al., 2020) and perform better than their competitors by efficiently and effectively modifying existing products or introducing new ones to the market that provide a superior benefit to customers (Deshpandé, Farley, \& Webster, 1993; Durmaz \& Eren, 2017). From a literature review on knowledge management and innovation, knowledge acquisition was pointed as a valuable and necessary process that contributes to the construction of innovation in organizations; innovativeness appears as a culture or the company's ability to be constantly updated; the capacity for product innovation directs the best performance in launching new products. When well aligned and related, these three elements positively impact the performance of organizations.

The Brazilian textile and clothing sector stands out on the world stage, not only for its professionalism, diversity, and technology but also for the size of its textile park: it is the sixth-largest industry in the world, the second-largest producer of denim (jeans), and the thirdlargest producer of knitwear. This sector includes the production of raw materials (natural and chemical fibers), through the weaving mills, to the final product (clothing, bed, and bath) (APEX BRASIL, 2020). Moreover, it is relevant for Brazilian economic and social development, accounting for $5.7 \%$ of the revenue of the entire local manufacturing industry and generating jobs and livelihoods for more than $16.4 \%$ of the workers (1.6 million). For this reason, the regular follow-up of the sector evolution is necessary for national development (IEMI, 2019).

This study aimed to test the relationship between knowledge management processes, innovativeness, and product innovation in the Brazilian textile sector.

Based on a study of 157 companies in Brazil's textile sector, the results showed that knowledge acquisition significantly impacts innovativeness, and innovativeness significantly impacts product innovation. Although knowledge acquisition does not directly affect product innovation, it has a strong indirect impact, fully mediated by innovativeness.

\section{THEORETICAL FRAMEWORK}

\subsection{Relationship between Knowledge Acquisition and Product Innovation}

The creation of organizational knowledge reflects the development of new products/services and is vital for companies that want to dominate the market. The management of the initial phase of this creation is fundamental to developing new products/services, as it determines the eventual destiny of a new product/service idea (Akbar \&Tzokas, 2013). Moreover, new 
knowledge can generate innovations in a company or lead to the emergence of innovations through synergies with already established knowledge (Aranda \& Molina-Fernandez, 2002). The intensive use of knowledge management tools can directly affect the company's performance, allowing not only the creation of knowledge-based synergies with partners but also the rapid acquisition of important information from the environment, leading to faster responses to market trends and needs (Vaccaro, Parente, \& Veloso, 2010).

Furthermore, the influence of specific network characteristics is fundamental to facilitate effective knowledge management for innovation (Gubbins \& Dooley, 2014). According to Lin, Che, and Ting (2012), there is a positive relationship between knowledge acquisition and product innovation, so that companies with a more effective acquisition, sharing, and use of market knowledge can better understand the dynamism of the context in which they operate and create innovative products to satisfy customers and market demands. Corroborating this idea, Yu, Chen, and Nguyen (2014) concluded that knowledge management is a critical antecedent to new product development.

Knowledge acquisition consists of a process that contributes to the construction of knowledge, and knowledge combinations result in new products (Yu et al., 2013). From the studies described, the first hypothesis of this research emerges:

H1 - Knowledge acquisition has a positive and significant impact on product innovation.

\subsection{Relationship between Knowledge Acquisition and Innovativeness}

Knowledge acquisition is linked to the capabilities and abilities to create the internal and absorb the external knowledge (Lichtenthaler \& Lichtenthaler, 2009). New knowledge helps renew the company's knowledge base (Yu et al., 2013) and promotes new ideas (Hsu \& Sabherwal, 2012).

The company's internal knowledge can be acquired through the training and instruction of

employees (Rusly \& Coner; SON, 2012), the reason why innovative organizations seek to finance and develop research and training activities (Guan \& Ma, 2003; Hii \& Neely, 2000; Lawson \& Samson, 2001; Martinez-Roman, Gamero, \& Tamayo, 2011). Moreover, internal acquisition can strengthen research and development and qualify the company's individuals, expanding its knowledge base (Rusly, Coner, \& Son, 2012). Competitive success arises from a dynamic process of capacity building, in which the acquisition, organization, integration, and use of knowledge collaborate to build innovativeness and new combinations of knowledge result in new products and processes (Yu et al., 2013).

Organizations that engage in innovative efforts cannot neglect external factors such as 
customer expectations and perceptions and competitors' strategies. Developing a culture of market orientation can facilitate strategic change and innovation in organizations (Yi et al., 2015; Chen et al., 2016; Wu, Chen \& Jiao, 2016; Kalali \& Heidari, 2016).

These processes impact the organizations' innovativeness by facilitating the control of market changes, managing the knowledge base, the contact and cooperation between internal and external agents, and the search for new and existing knowledge in the company's base (Yu et al., 2013). Knowledge acquisition positively relates to innovativeness for three reasons: (i) new knowledge enables and leverages the generation of innovations; (ii) more knowledge can provide a greater variety of combinations and collaborate to creativity and the development of new products; and (iii) by acquiring knowledge, the company can reduce uncertainties and risks inherent to business and, more specifically, to the development and launch of new products in the market (Kör \& Maden, 2013; Liao et al., 2010). From these considerations, the second research hypothesis emerges:

H2 - Knowledge acquisition has a positive and significant impact on innovativeness.

\subsection{Relationship between Innovativeness and Product Innovation}

Innovative companies develop an arrangement of peculiar skills and competencies that balance the admission and generation of innovations (Damanpour \& Wischnevsky, 2006; Lawson \& Samson, 2001), providing an infrastructure and a resource base that support the identification, selection, and prodúction of innovations (Martinez-Roman, Gamero, \& Tamayo, 2011). This type of company institutes vision, strategies, values, and principles, as well as an organizational culture, directed toward innovation, stimulating risk-taking, creativity, organizational learning, and the interaction of experiences (Hii \& Neely, 2000; Lawson \& Samson, 2001), factors that can have a positive impact on the launching of new products.

Organizations can then develop a possible competitive advantage by adopting innovative behavior. On the one hand, firms can perform better than their competitors by efficiently and effectively modifying existing products or introducing new products to the market that provide customers with superior value and benefits (Deshpandé, Farley, \& Webster, 1993;

Durmaz \& Eren, 2017). On the other hand, competitive intensity leads to a price war that can discourage firms from investing in innovation (Theodosiou et al., 2012).

As innovation and innovation capacity are vital to firms' performance and competitiveness, there is the need to place innovation and innovation capacity closer to the innovation strategy, conceiving production strategy as a component of business strategy (Kilic et al., 2015). 
Innovation capacity influences market orientation, product innovation, and firm performance (Verhees \& Meulenberg, 2004). Therefore, innovation strategy, understood as a marketing initiative, assumes a key role in product innovation performance so that firms with greater innovation capacity are more successful in responding to their environment and developing new capabilities, providing competitive advantage and superior performance (Hurley \& Hult, 1998; Racela, 2014; Matte et al. 2020).

In a study in the metal-mechanic sector, De Toni et al. (2019) observed that a culture focused on innovation has a direct and positive impact on the development of new products, presenting an indirect effect on the performance of organizations. Furthermore, the authors evidenced that the number of new products developed mediates the relationship between innovativeness and the performance of these organizations. The positive relationship between innovativeness and product innovation was empirically confirmed by Urhahn and Spieth (2014), giving rise to the third hypothesis of this research:

H3 - Innovativeness has a positive and significant impact on product innovation.

\subsection{Factors Moderating Product Innovation}

Moderators are quantitative or qualitative variables that affect the direction and/or strength of a relationship between an independent and a dependent variable (Baron \& Kenny, 1986). According to Hair Jr. et al. (2018), the moderating effect occurs when a third variable or a third construct changes the relationship between two variables or two related constructs. This study proposed that the organization type of activity can moderate the relationship between innovativeness and product innovation.

The textile and clothing sector in Brazil is one of the most traditional and complex industrial sectors globally. With a long production chain, beginning in the production of fibers and filaments, passing through stages such as spinning, weaving, knitting, finishing, and apparel, its industries - or at least part of them - are present all over the planet, from developed countries to countries with lower relative economic development (CNI, 2019).

Knitting is prominent among the various existing fabrics today, one of the oldest and most widely used manufacturing processes. Currently, there are two primary forms of its production: circular and rectilinear. Circular knitting uses a widely known technique in the textile industry, named because of the circular looms that produce a tubular fabric whose diameter will depend on the number of needles used in the process. Rectilinear knitting, on the other hand, is characterized by producing airy fabrics, from looms that the carriage moves, taking the threads from one side to the other of its length, and in which the needles are 
immobile in the formation of stitches or loops that shape the knit (Grupo JB Tecidos, 2017). Rectilinear knitting is suitable for larger diameter yarns, such as knit and crochet, present mainly in making clothes and characterizing one of the first processes used to form knitwear mills. During the early years of industrial production, the human operation was necessary for several process stages; today looms work in an automated way (Grupo JB Tecidos, 2017). In line with these considerations, the fourth and last research hypothesis was formulated: H4 - The type of activity moderates the relationship between innovativeness and product innovation, with such a relationship being stronger in weavers and circular knitting.

Figure 1 presents the proposed theoretical model and the research hypotheses to illustrate the relationships between the constructs.

\section{Figure 1 about here}

\section{Research Method}

The approaches used in the research were quantitative and qualitative. The quantitative step was carried out before the qualitative step in a sequential approach. The qualitative approach helped understand the statistical results and added knowledge of the sociocultural context $a$ posteriori (Kelle, 2006).

\subsection{Target Population, Sample, and Data Collection}

The study object of the research was composed of Brazilian industries in the textile sector, registered in the Sector Report of the Brazilian Textile Industry - Brazil Textile 2014 - and associated with the Brazilian Association of the Textile and Clothing Industry (ABIT). According to the Institute of Industrial Studies and Marketing (IEMI), the industrialization process in Brazil began with the textile industry. Its history and roots predate the arrival and occupation of the Portuguese, as the Indians who inhabited the country already carried out craft activities and used primitive techniques such as the manual interweaving of vegetable fibers to produce coarse canvas, with the primary purpose of body protection (IEMI, 2019). The textile industry is one of the most widespread globally, constituting an essential income and employment generation source for several developing countries (IEMI, 2019).

The research sample composed 157 industries registered with IEMI, 2014 edition, chosen from a total of 377 companies registered in the rectilinear knitting and weaving sector. Data collection occurred from September 2015 to April 2016 in five waves of research. One of the researchers contacted the selected organizations by phone to speak with the marketing 
manager. When it was impossible to talk to the manager, we requested to e-mail the questionnaire. At each contact, the researcher provided a brief explanation about the theme and relevance of the research, the importance of participation in the study, and the questionnaire application.

\subsection{Data Analysis}

Data analysis was performed using two statistical techniques: structural equation modeling (Kline, 2015; Byrne, 2016) and mediation and moderation tests (Jose, 2013; Osborne, 2014). The confirmatory factor analysis occurred with structural equation modeling and the use of Microsoft Office Excel® 2013, Statistical Package for the Social Sciences (SPSS $® 21$ ), and Analysis of Moment Structures (Amos® 20) software.

The assumptions of the multiple regression analysis were verified to guarantee the greater robustness of the sample. The homoscedasticity condition was analyzed based on Box's M and Levene's tests, and the linearity condition was evaluated based on the plot of the standardized residuals (Hair Jr. et al., 2018; Malhotra et al., 2012). By checking the scatterplots, we found that the variables in the model studied presented linear relationships. Finally, multicollinearity was ascertained through the tolerance test, showing that all variables showed acceptable levels, with the tolerance between the values of 0.15 and 0.76 and, for the variance inflation factor (VIF), from 1.42 to 6.53 , indicating that multicollinearity was not a problem concerning the selected variables (Hair Jr. et al., 2018; Malhotra et al., 2012). In order to identify direct and indirect relationships between the constructs, mediation tests and the linear regression technique were applied, based on the procedures indicated by Preacher and Hayes (2004) and Zhao, Lynch, and Chen (2010), using the bootstrapping test, with a $95 \%$ confidence interval.

\subsection{Operationalization of the Constructs and Respective Variables}

The data collection instrument was composed of 24 variables validated in previous studies and adapted to the context of this research. The scale of Gold, Malhotra and Segars (2001) was used for the construct knowledge acquisition, the scale of Calantone, Cavusgil and Zhao (2002) for the construct innovativeness, and the scale of Darroch (2005) for the construct product innovation. A Likert-type scale was used for all constructs, ranging from 1 (strongly disagree) to 7 (strongly agree).

Table 1 presents the scales used, their respective variables (scale items), the confirmatory factor analysis, and constructs' reliability. 


\section{Table 1 about here}

The results of the factor analysis of the measurement model (Table 1), with the three factors and the adjustment of the variables to their factors (latent constructs), indicated factor loadings above $0.50, \mathrm{KMO}$ of 0.92 , Bartlett's test of sphericity of 0.000 , and an explained variance of 62.94\%, revealing satisfactory findings (Mulaik, 2010; Gorsuch, 2015).

Regarding reliability, all constructs showed Cronbach's alpha above the recommended by the literature, which is 0.70 (Hair et al., 2018; Malhotra et al., 2012). Concerning convergent validity, all values evidenced a variance extracted (AVE) greater than 0.50 .

Regarding the methods used, Podsakoff et al. (2003) commented that the method bias is a problem because it is one of the primary sources of measurement errors and that Harmon's one-factor test is one way to identify this bias. In this research, Harmon's test identified that a single factor explains $44.72 \%$ of the total variance, indicating no significant impact of method bias on the measurement. To test how much the constructs were related to each other, their correlations were analyzed. The results expressed in Table 2 show that all constructs present a significant correlation with each other.

\section{Table 2 about here}

Fornell and Larcker's (1981) test was used for the discriminant validity analysis. Table 3 presents the results.

\section{Table 3 about here}

Although the shared variance of product innovation with innovativeness has been greater than the extracted variance $(0.75)$, we decided to keep these constructs because a solid theoretical basis supports two independent constructs. It should also be noted that the moderator variable used in this study is the type of activity, assigning "0" for weaving and circular knitting, corresponding to 85 companies $(54.1 \%)$, and "1" for clothing and rectilinear knitting, including 72 companies (45.9\%).

\section{Results}

\subsection{Sample Characterization and Analysis of Variance}


Information on the profile of the companies included the time of the founding, the type of activity, and the number of employees. Of the 157 companies surveyed, 133 are more than 15 years $(84.71 \%)$, nine are between 10 and 15 years old (5.73\%), and 14 are less than ten years old $(8.92 \%)$. Concerning the type of activity, 85 companies are circular knitters and weavers $(54.1 \%)$, and 72 are clothing and rectilinear knitters $(45.9 \%)$. As for the number of employees, 43 companies have up to 99 employees (27.4\%), 83 have between 100 and 499 (52.9\%), and 31 have more than 500 employees (19.7\%).

The analysis of variance (ANOVA), employed to evaluate the variation between groups (Warner, 2013) concerning the time of the founding, the type of activity, and the number of employees, identified no significant difference among the analyzed constructs (knowledge acquisition, innovativeness, and product innovation). This result indicates some homogeneity in the evaluation of the constructs of these three demographic variables.

\subsection{Structural Model Validation and Hypotheses Testing}

The validation of the structural model and hypotheses testing identified acceptable model fit indexes (CFI: 0.925, IFI: 0.926, TLI: 0.913, RMSEA: 0.074, CMIN: 406.039, DF: 218).

Table 4 presents the results of the hypothesis testing.

\section{Table 4 about here}

According to the results presented, hypotheses $\mathrm{H} 2$ (knowledge acquisition has a positive and significant impact on innovativeness, $\beta=0.770, \mathrm{p}<0.001$ ) and $\mathrm{H} 3$ (innovativeness positively influences product innovation, $\beta=0.979, \mathrm{p}<0.001$ ) were statistically confirmed. However, $\mathrm{H} 1$, which concerns the positive influence of knowledge acquisition on product innovation, was not statistically supported $(\beta=-0.139, \mathrm{p}=0.208)$.

The coefficient of determination $\left(\mathrm{R}^{2}\right)$ defines how much the independent variables explain the variation of the dependent variable. Innovativeness presented a value of 0.592 (59.2\%) and product innovation of 0.768 . This result shows that the independent variables explain $76.8 \%$ of product innovation, indicating a high explanatory power (Tabachnick \& Fidell, 2012). Hence, although the model is relatively simple, innovativeness and knowledge acquisition strongly explain product innovation.

\subsection{Estimation and Evaluation of Mediating and Moderating Effects}

Moderators are quantitative or qualitative variables that affect the direction and/or strength 
between an independent and a dependent variable (Baron \& Kenny, 1986). According to Hair Jr. et al. (2018), a moderator effect occurs when a third variable or a third construct changes the relationship between two variables or two related constructs. Moderator effects allow for a more segmented understanding of the relationship between variables from different aspects of the research object. We aimed to assess whether the type of activity moderates the relationship between innovativeness and product innovation based on moderation tests. As suggested by $\mathrm{H} 4$, such moderation is stronger in weaving and clothing because this field presents a higher level of market demands regarding product innovation. The weaving subsector launches fashion trends that include applying technologies to the raw material used - in colors, textures, and functionalities - adding value to the finished product. The confections are responsible for finishing the product, applying modeling design, and adding cutting and sewing technologies. As the fabrics in weaving and clothing have technologies focused on health, sports, comfort, and visual design, these subsectors have influenced the relationship between innovativeness and product innovation. These technologies are applied at the base of the fabric and its functionalities elaboration and finishing the pieces, making these subsectors stand out for product innovation.

The mediating effect in a measurement model occurs when an independent variable affects a dependent variable of interest (Baron \& Kenny, 1986; Hair et al., 2009). According to Zhao, Lynch, and Chen (2010), the indirect effect of the independent variable on the dependent variable must be significant for mediation to be found. Furthermore, for significant mediation to exist, the path between the independent, mediating, and dependent variables must be significant. Zhao, Lynch, and Chen (2010) further pointed out that for complete mediation, the direct effect of the independent variable on the dependent variable must be insignificant. Then, when the direct effect of the independent variable on the dependent variable is significant, mediation will be partial.

In testing hypothesis $\mathrm{H} 4$, the relationship between knowledge acquisition and product innovation was negative and not significant for the sample investigated in the textile sector. Hence, to identify how much innovativeness mediates the relationship between knowledge acquisition and product innovation, the procedure proposed by Hayes (2013) was performed through PROCESS and SPSS, using plot 14. A 95\% confidence interval calculated through 5.000 resamples in the bootstrapping procedure was used for all results, as shown in Figure 2.

\section{Figure 2 about here}


Figure 2 illustrates that the type of activity of the firms has a significant relationship for both weaving and clothing. However, the relationship between innovativeness and product innovation is stronger and more significant for weaving and circular knitting activities, confirming $\mathrm{H} 4$.

\subsection{Qualitative Phase}

The hypotheses tested and confirmed in the quantitative phase are explained by existing studies, while rejected hypotheses do not have the same advantage. Therefore, the qualitative step aimed to overcome this lack and refine the knowledge generated by the quantitative phase. Ten specialists from textile companies were interviewed to understand why those hypotheses were not confirmed. The content analysis technic was used with the help of NVivo®11.

Hypothesis H1 (positive relationship between knowledge acquisition and product innovation) was rejected in the quantitative tests. The result of the qualitative analysis showed that the direct positive relationship between knowledge acquisition and product innovation might not occur in large companies, which need to process the acquired knowledge. However, it pointed out that it would be ideal to acquire knowledge and generate product innovation directly.

\section{Discussions}

The hypotheses test results do not confirm $\mathrm{H} 1$, indicating that knowledge acquisition did not positively and significantly impact product innovation $(\beta=-0.139 ; p=0.208)$. The nonconfirmation of this hypothesis is an interesting result since the theoretical background indicated a positive relationship between knowledge acquisition and product innovation (Aranda \& Olina-Fernandez, 2002, Lin, Che, \& Ting, 2012, Yu, Chen, \& Nguyen, 2014). However, this may be a specific characteristic of the Brazilian textile sector, in which knowledge acquisition may not have a direct, but rather an indirect, relationship with product innovation.

Furthermore, from the qualitative interviews with entrepreneurs in the textile sector, innovativeness constitutes an essential and behavioral factor that enables product innovation and may justify the non-direct relationship between knowledge acquisition and product innovation. The company must be proactive in creating an innovative product, whether in utility, technology, or design. When the company perceives the need to obtain new knowledge and innovations, it invests and becomes innovative. This idea was complemented by the qualitative results, demonstrating that large companies with organized processes practice the 
knowledge management processes linearly and sequentially to generate product innovation. On the other hand, $\mathrm{H} 2$ was confirmed, and knowledge acquisition significantly impacted innovativeness $(\beta=0.770 ; \mathrm{p}<0.001)$. This result corroborates the findings of Bidmeshgipour, Ismail and Omar (2012), who identified that knowledge acquisition is positively related to innovativeness. In this regard, Yu et al. (2013) stated that knowledge acquisition is a process that contributes to the construction of innovativeness, allowing the monitoring of the market (Yu et al., 2013) and obtaining knowledge about hidden and contemporary interests (Gold, Malhotra, \& Segars, 2001; Hoe \& Mcshane, 2010; Huber, 1991). Such knowledge originated from partners, competitors, consumers, or suppliers (Bresman, Birkinshaw, \& Nobel, 1999; Huber, 1991). An increase in new knowledge helps to improve the company's knowledge base (Yu et al., 2013) and enables the manifestation of new ideas (Hsu \& Sabherwal, 2012), allowing the identification and selection of innovation opportunities (Adler \& Shenhar, 1990; Lawson \& Samson, 2001; Martinez-Roman, Gamero, \& Tamayo, 2011) and, consequently, reinforcing research and product development (Rusly, Coner, \& Son, 2012).

Innovativeness also exerts a positive and significant impact on product innovation, confirming H3 $(\beta=0.979 ; \mathrm{p}<0.001)$. Therefore, companies that achieve the acquisition and production of innovation can adapt to external changes, new conditions, and alternatives created by themselves (Damanpour \& Wischnevski, 2006). Innovative firms offer an arrangement of skills and competencies that balance the admission and generation of innovations (Damanpour \& Wischnevsky, 2006; Lawson \& Samson, 2001) and provide an infrastructure and resource base that enables them to identify, select, and produce innovations (Martinez-Roman, Gamero, \& Tamayo, 2011). In addition, innovativeness enhances the vision, strategy, and cultural values that support the acquisition and production of innovation (Hii \& Neely, 2000; Lawson \& Samson, 2001) in business practices, ways of working, and external relationships, stimulating cost reduction, increased profits, and productivity (Ganter \& Hecker, 2013).

In response to the non-confirmation of $\mathrm{H}_{1}$, we observed that innovativeness presents complete mediation (Zhao, Lynch, and Chen, 2010). Although the direct effect of knowledge acquisition on product innovation is not significant, the total effect (combination of direct and indirect effects) is significant $(\beta=0.716, \mathrm{p}<0.05)$, indicating the mediation of the other constructs on the direct relationship.

Knowledge acquisition consists of a process that contributes to innovativeness since new combinations of knowledge result in new products (Yu et al., 2013). It should also be noted that the acquisition process is positively associated with innovativeness, which in turn, is configured as the knowledge management process, positively associated with innovation 
performance. Consequently, innovativeness mediates the relationship between the knowledge management process and innovation performance (Yusr et al., 2014).

Companies that constantly seek knowledge acquisition from a market orientation focus on learning both the unmet and the latent needs of their customers (Narver, Slater, \& MacLachlan, 2004). According to Gibbert et al. (2002) and Lettl et al. (2006), interaction with customers and users is considered an essential antecedent of innovation results for organizations. Therefore, both internal and external knowledge acquisition and culture for innovation are strongly associated with performance in product innovation.

\section{Final Considerations}

In the form of an organizational culture focused on the constant search for innovation, innovativeness constitutes one of the critical factors for product and service innovation. This research, based on the analysis of 157 companies in the Brazilian textile sector, highlights three significant contributions: the proposition and testing of a theoretical model that identifies two significant constructs that can positively impact product innovation; the identification of the mediation of innovativeness in the relationship between knowledge acquisition and product innovation, as well as the moderation impact of the type of activity on these constructs.

As for the proposition, testing, and validation of the proposed theoretical model, the variance explained of the model is $77 \%$, indicating a significant influence of the independent and moderating variables on the dependent variable (product innovation). Of the two antecedent constructs tested, for the companies analyzed, innovativeness was the one that had a more significant impact on product innovation. This result signals the importance of companies being innovative in their products/services (or processes) to sustain a competitive advantage and add more value to their customers, consequently increasing their market performance. Regarding the moderator variable (type of activity), we initially assumed that the type of activity of firms moderated the relationship between innovativeness and product innovation. Surprisingly, such moderation was not fully confirmed since both the weaving and circular knitting and the clothing and rectilinear knitting activities showed a significant relationship between these two constructs. However, this relationship is stronger for the weaving and clothing subsectors $(\beta$ weaving $=0.53$ versus $\beta$ clothing $=0.42)$.

In this study, the weaving and clothing subsectors complement each other in product innovation because weaving creates fabric and clothing designs. In other words, both are part of a product creation and finalization process, and one depends on the other to create a new 
fashion collection that can be in the form of clothing, footwear, home or automotive decoration coverings, or items used in the health area. Previous studies identified the direct impact of innovativeness on product innovation (Aranda \& Olina-Fernandez, 2002; Lin, Che, \& Ting, 2012; Yu; Chen \& Nguyen, 2014). However, the present study set in the Brazilian textile sector did not identify this significant and positive relationship, which does not mean that knowledge acquisition is not an important element for product innovation. The qualitative analysis showed that the direct positive relationship between knowledge acquisition and product innovation might not occur in large companies, which need to process the acquired knowledge.

The mediation tests showed that knowledge acquisition has an indirect effect on product innovation, fully mediated by innovativeness. Knowledge acquisition enables a better maturation of the organization, and a greater understanding of market changes, allowing to create and deliver more innovative products or services capable of adding value to the customer.

It is noteworthy that, no matter how rigorous research is performed, every study may present some limitations. In this research, since a convenience sample was used, it does not portray the configuration of the proposed model for the Brazilian textile sector. Consequently, this model could not be generalized either for this or other sectors. A research suggestion is to investigate the proposed model in another market segment and verify whether the direct relationship between knowledge acquisition and product innovation can be confirmed. Another limitation of this study is that it did not investigate the impact of product innovation on the financial and market performance of the organizations analyzed. Otherwise, future studies may address knowledge management from the four main processes presented by Takeuchi and Nonaka (2009), Alavi and Leidner (2001), and Anand and Singh (2011): the acquisition, sharing, storage, and application of knowledge. These constructs should be related to companies' innovativeness, product innovation, and market or economic-financial performance to deeply understand the impact of a better skill in product development for companies (Panizzon et al., 2020). Finally, analyzing the number of new products launched in recent years and the implementation of new technologies is also suggested to ascertain how these aspects can moderate the relationship between knowledge management and innovation in organizations. 
purposes and advantages. Qualitative research in psychology, 3(4), 293-311.

https://doi.org/10.1177/1478088706070839.

Kilic, K., Ulusoy, G., Gunday, G., \& Alpkan, L. (2015). Innovativeness, operations priorities and corporate performance: An analysis based on a taxonomy of innovativeness. Journal of Engineering and Technology Management, 35, 115-133.

https://doi.org/10.1016/j.jengtecman.2014.09.001

Kline, R. B. (2015). Principles and practice of structural equation modeling. ${ }^{\text {th }}$ edition. New York: The Guilford Press.

Kör, Burcu; Maden, Ceyda. (2013). The relationship between knowledge management and innovation in turkish service and high-tech firms. International Journal of Business and Social Science, 4(4), 293-304.

Lawson, B., \& Samson, D. (2001). Developing innovation capability in organisations: a dynamic capabilities approach. International journal of innovation management, 5(03), 377400. https://doi.org/10.1142/S1363919601000427.

Liao, S. H., Wu, C. C., Hu, D. C., \& Tsui, K. A. (2010). Relationships between knowledge acquisition, absorptive capacity and innovation capability: an empirical study on Taiwan's financial and manufacturing industries. Journal of Information Science, 36(1), 19-35. https://doi.org/10.1177/0165551509340362

Lichtenthaler, U., \& Lichtenthaler, E. (2009). A capability-based framework for open innovation: Complementing absorptive capacity. Journal of Management Studies, 46(8), 1315-1338. https://doi.org/10.1111/j.1467-6486.2009.00854.X

Lin, R. J., Chen, R. H., \& Chiu, K. K. S. (2012). Customer relationship management and innovation capability: an empirical study. Industrial Management \& Data Systems, 110(1), 111-133.

Malhotra, N. K., Birks, D., \& Wills, P. (2012). Marketing research: applied approach. ${ }^{4 \text { th }}$ edition. New York: Pearson.

Martínez-Román, J. A., Gamero, J., \& Tamayo, J. A. (2011). Analysis of innovation in SMEs using an innovative capability-based non-linear model: A study in the province of Seville (Spain). Technovation, 31(9), 459-475. https://doi.org/10.1016/j.technovation.2011.05.005. Matte, J., Milan, G. S., Ganzer, P. P., Graciola, A. P., Chais, C., \& Olea, P. M. (2020). A influência das capacidades especializadas de marketing e da orientação empreendedora no desempenho do comércio varejista de vestuário. Revista Brasileira de Marketing, 19(1), 106125. https://doi.org/10.5585/remark.v19i1.17136.

Mulaik, S. A. (2010). Foundations of factor analysis. ${ }^{2 n d}$ edition. Boca Raton: Taylor \& 
innovation-A quantitative analysis on the relationship between portfolio management governance, portfolio innovativeness, and firm performance. IEEE Transactions on Engineering Management, 61(3), 522-533. https://doi.org/10.1109/TEM.2014.2327254. Vaccaro, A., Parente, R., \& Veloso, F. M. (2010). Knowledge management tools, interorganizational relationships, innovation and firm performance. Technological Forecasting and Social Change, 77(7), 1076-1089. https://doi.org/10.1016/j.techfore.2010.02.006 Verhees, F. J., \& Meulenberg, M. T. (2004). Market orientation, innovativeness, product innovation, and performance in small firms. Journal of Small Business Management, 42(2), 134-154. https://doi.org/10.1111/j.1540-627X.2004.00102.x.

Wang, Catherine L.; Ahmed, Pervaiz K. (2004). The development and validation of the organisational innovativeness constructo using confirmatory factor analysis, European Journal of Innovation Management, 7(4), 303-313. https://doi.org/10.1108/14601060410565056.

Warner, R. M. (2013). Applied statistics: from bivariate through multivariate techniques. ${ }^{\text {2nd }}$ edition. Thousand Oaks: Sage Publications.

Wu, H., Chen, J., \& Jiao, H. (2016). Dynamic capabilities as a mediator linking international diversification and innovation performance of firms in an emerging economy. Journal of Business Research, 69(8), 2678-2686. https://doi.org/10.1016/j.jbusres.2015.11.003.

Yi, Y., He, X., Ndofor, H., \& Wei, Z. (2014). Dynamic capabilities and the speed of strategic change: Evidence from China. IEEE Transactions on Engineering Management, 62(1), 18-28. https://doi.org/10.1109/TEM.2014.2365524.

Yusr, Maha Mohammed; Othman, Abdul Rahim; Mokthar, Sany Sanuri Mohd; Don, Mohd Sobri. (2014). How innovation capability can be a mediate between knowledge management and innovation performance? International Business Management, 8 (2), 118-125.

Yu, Y., Dong, X. Y., Shen, K. N., Khalifa, M., \& Hao, J. X. (2013). Strategies, technologies, and organizational learning for developing organizational innovativeness in emerging economies. Journal of Business Research, 66(12), 2507-2514.

https://doi.org/10.1016/j.jbusres.2013.05.042.

Yu, X., Chen, Y., \& Nguyen, B. (2014). Knowledge management, learning behavior from failure and new product development in new technology ventures. Systems Research and Behavioral Science, 31(3), 405-423. https://doi.org/10.1002/sres.2273.

Zhao, X., Lynch Jr, J. G., \& Chen, Q. (2010). Reconsidering Baron and Kenny: Myths and truths about mediation analysis. Journal of Consumer Research, 37(2), 197-206.

https://doi.org/10.1086/651257. 